\title{
An Analysis of Student Responses in Online Learning-Based Comic Video Module Creative Realistic Mathematics On Integer Operation Material
}

\author{
Tetty Natalia Sipayung ${ }^{*}$, Imelda ${ }^{2}$, Tatag Yuli Eko Siswono ${ }^{3}$, Masriyah $^{4}$ \\ ${ }^{1,2}$ Universitas Katolik Santo Thomas, Indonesia \\ ${ }^{3,4}$ Department of Mathematics Education, State University of Surabaya, Indonesia \\ tetty_sipayung@ust.ac.id
}

\begin{abstract}
Everyone's perspective is different. Likewise, the student's perspective on mathematics. It is undeniable that most childran claim that mathematics is difficult. Behind the statement, of course, there is a reason for the child. This is related to student responses when studying in mathematics class. One alternative to knowing student responses can be found by conducting research. Therefore, qualitative research is needed to analyze student responses. The application of learning using creatibe module comics based on a realistic mathematics approach has been implemented for all students of class VII-B at SMP Santo Yoseph Medan in the 2020/2021 Academic Year. In this study students' responses to the application of learning were analyzed specifically for integer operation material. The learning is carried out online based on the creative realistic mathematics video comic module in the Google Classroom. The instrument used was a student response questionare which was presented via google form. Based on the results of data collection that has been done, it is concluded that the student's responses are positive to learning using the creative module comic based on realistice mathematics approach. It is based on obtaining a high score on the average percentage of interest and benefits that students derive from implementation.
\end{abstract}

Keywords response; comic; creative module

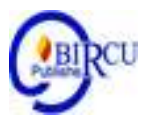

\section{Introduction}

Education is a basic need for everyone. Education that generally applies in a formal environment is school education. In taking education at school, a person needs to experience the process through learning activities in the classroom. Students and teachers are required to interact with each other so that learning is two-way and not monotonous. Therefor it is necessary to choose a learning model. The selection of the correct learning model is an effort to activate students in the learning process and improve student achievement (Husna, Dwi Wahyuni, Suratno, I Ketut Mahardika, and lis Nur Aisyah, 2018: 408). Teachers need to acquire a set of skills, which include learning to pay attention, analyze and then respond to the responses of students 'ideas and ideas to support students' ideas and channel them as knowledge development (Dalvi, T. and Anna Hofmann, 2019: 333). If the mobile-based student response system is technically feasible to be applied in schools and if the students' perceptions are positive using such a system, then the teacher can use it in the classroom to increase student involvement and to identify poor performers (Wong, A., 2016: 145) Smith, M. S., \& Stein, M. K. (2011) stated that 
awareness of learning is the key to development that can help a teacher anticipate general student responses and monitor student discussions both throughout the class or small groups (M. Wright, C., 2018).

Education is considered to have a very important role in promoting the civilization of a nation. Good quality education can encourage the creation of a quality society, creative and productive until finally able to achieve welfare. Through this national education system, the government should be able to ensure equal distribution of educational opportunities, as well as the relevance and efficiency of education management to face challenges in line with the changing demands of local, national and global life. (Saputra, 2018)

Education is key to the progress of a nation. As Iwantoro has put forward (2014:53) education is a very important issue in the development of this nation and the country. The purpose of Education is to direct the growing potential of learners to be a man of pious care to the One God Almighty, qualified, possessed of sublime pekerti ability and virtuousness. Education has a very strategic role in determining the direction of the forthcoming of the nation's quality of community knowledge. (Musdiani et al, 2019)

Education is one of the efforts to improve the ability of human intelligence, thus he is able to improve the quality of his life. So, to create the highest quality of human resources, education is becoming an important factor to be considered. The importance of education is also reflected at MPR No. II/MPR/1993 which states that the national education aims to improve the quality of Indonesia people that is religious people, and pious to God Almighty, noble character, has high personality, discipline, work hard, responsible, independent, smart, healthy, physically and mentally healthy. (Sugiharto in Harahap, 2020)

Student response in learning is related to interest. One of the media that can be used to support students' interest in learning who is slow in learning is comics (Dwi Arinii, F., Abdul Salim Choiri, Sunardi, 2017: 72). The use of comic media is one way to improve students' reading skills. Comics are included in the visual media category. Comics can also be used as an alternative in improving student learning performance through pictures, because comics are very interesting in student life (Afwun Kamil, Endang Komariah, and Yuliana, 2017: 2). Comics and stories are topics that are interesting and familiar to children (Deligianni, A.-Georgaka and Qurania Pouroutidi, 2016: 234). Today's teenagers are surrounded by a variety of media and are increasingly complex, but in some circumstances the classroom material is found to be boring, irrelevant, or both. But by placing comics that students already recognize in the context of the classroom, it can help teachers to identify weak students in a positive way (Versac, R., 2001: 62). Digital comics can be used as interactive teaching materials for teachers (A. Mamolo, L., 2019: 13).

Comics contain a high element of art and the content of comics not only presents material but also provides a touch of humor through the pictures and stories in it so that students who read comics are not learning about mathematics material. In addition, comic messages in the form of knowledge, problems are conveyed clearly, coherently and pleasantly (Meilantifa, et. Al., 2019: 1). Comics can be designed and used immediately to teach certain concepts.

Comics can be developed by applying realistic mathematics learning. Based on the result of research conducted by Celsie Puji Lestari, A. and Rooselyna Ekawati (2019) that realistic mathematics education comics on fraction material that have been developed are valid, effective, and can be used to improve student learning outcomes. This is in line with 
research conducted by Sipayung, T. N., Sinta Dameria Simanjuntak, Ariyadi Wijaya, and Sugiman (2019) that realistic mathematics comics can improve students' conceptual understanding skills. However, the results of previes research were applied to offline learning systems. Give the Covid-19 throughy the Google Classroom application. Through online learning that is applied it necessary to analyze student responses. Therefore, a qualitative research was carried out, namely the analysis of student responses to learning using comic video of realistice mathematics creative modules.

\section{Research Methods}

This research is a qualitative research with descriptive methods. The subjects of this study were 31 students of class VII-B SMP Santo Yoseph Medan and their responses to learning using realistic mathematics creative module comics in online learning. Online learning is carried out based on comic videos of realistic mathematics creative modules in Google Classroom. There are two videos that were distributed to class VII-B students on Google Classroom, namely a comic video on a creative realistic mathematics module and a video explaining integer operation material. The display of the sharing of realistic mathematics creative module comic videos to students in Google Classroom can be seen in the image below:

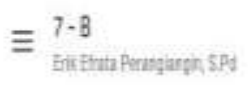

\section{(c) Video Komik Modul Materi 1 Ruang MTK Kreatif : ieny Nurata + hig 10}

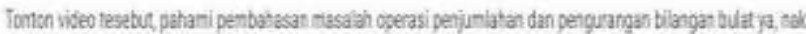
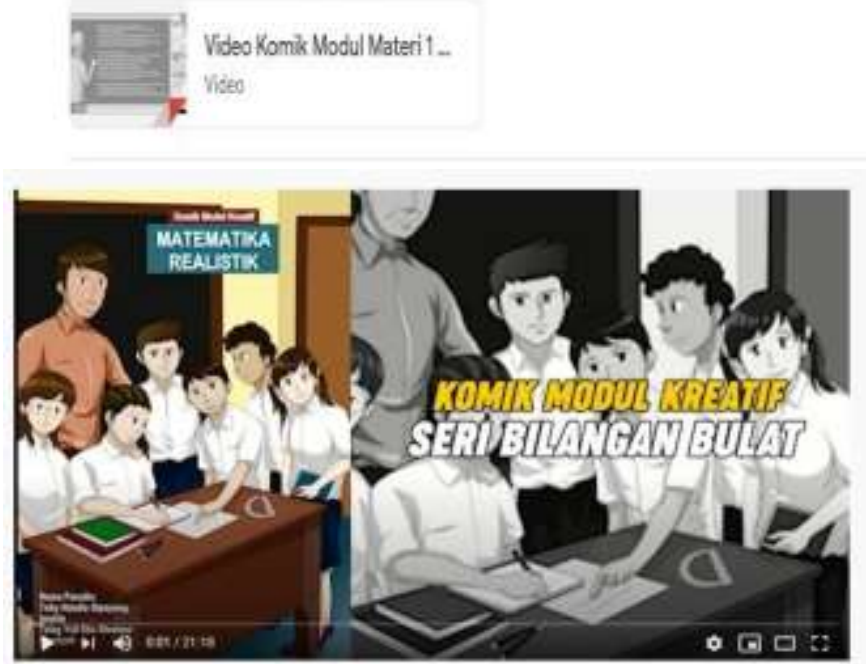

Kamik Modue Kreant Seri Afangan Bdat I Fliang MTK Kueatif

Figure 1. Video Comic Module Creative Realistic Mathematics in Google Classroom 


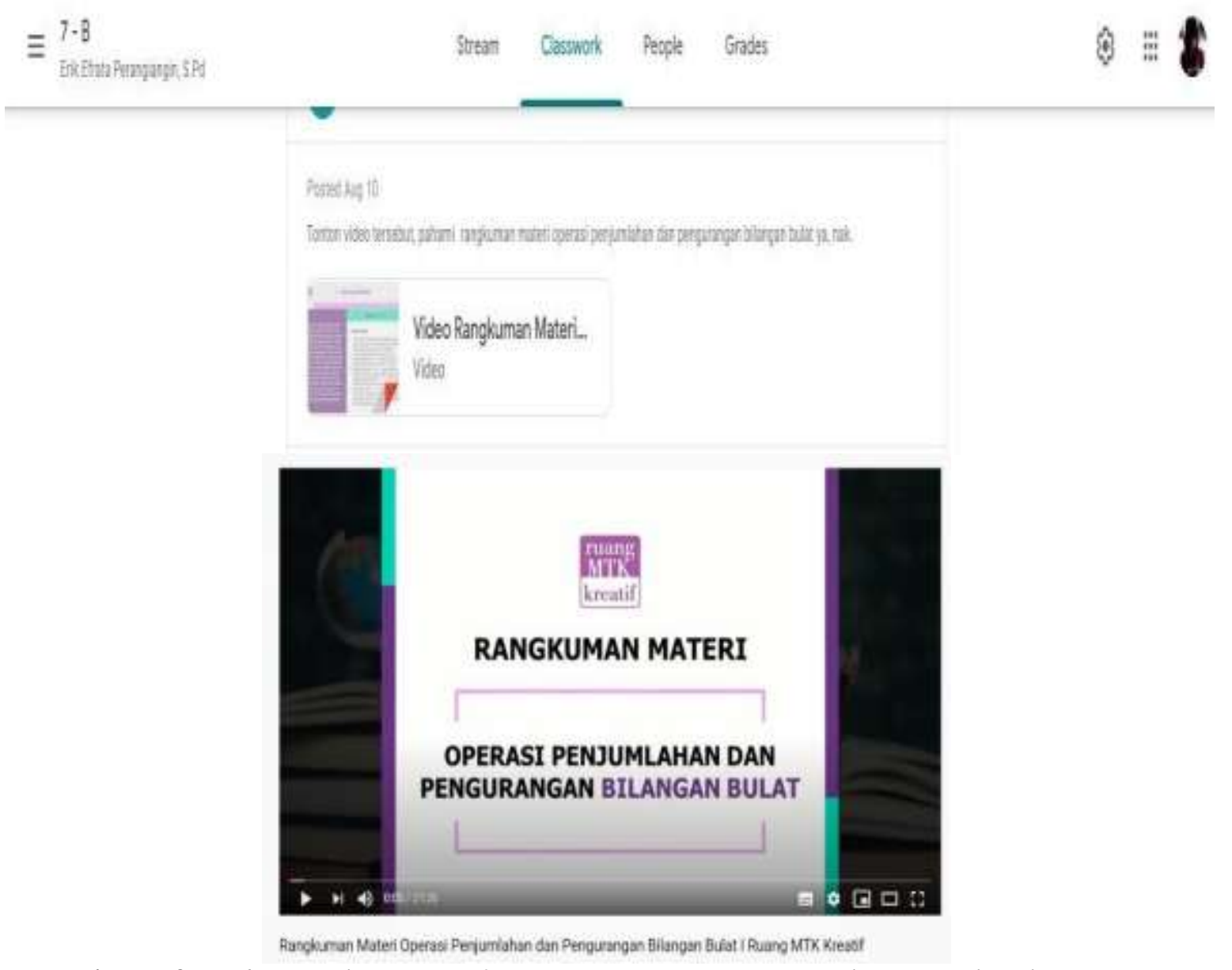

Figure 2. Video Explanation of Integer Operation Material in Google Classroom

This research was conducted in the odd semester of the 2020/2021 Academic Year specifically on integer operation material. The research instrument includes a student response questionnaire to the applied learning methods and approaches designed in Google Form, which can be seen in the following figure:

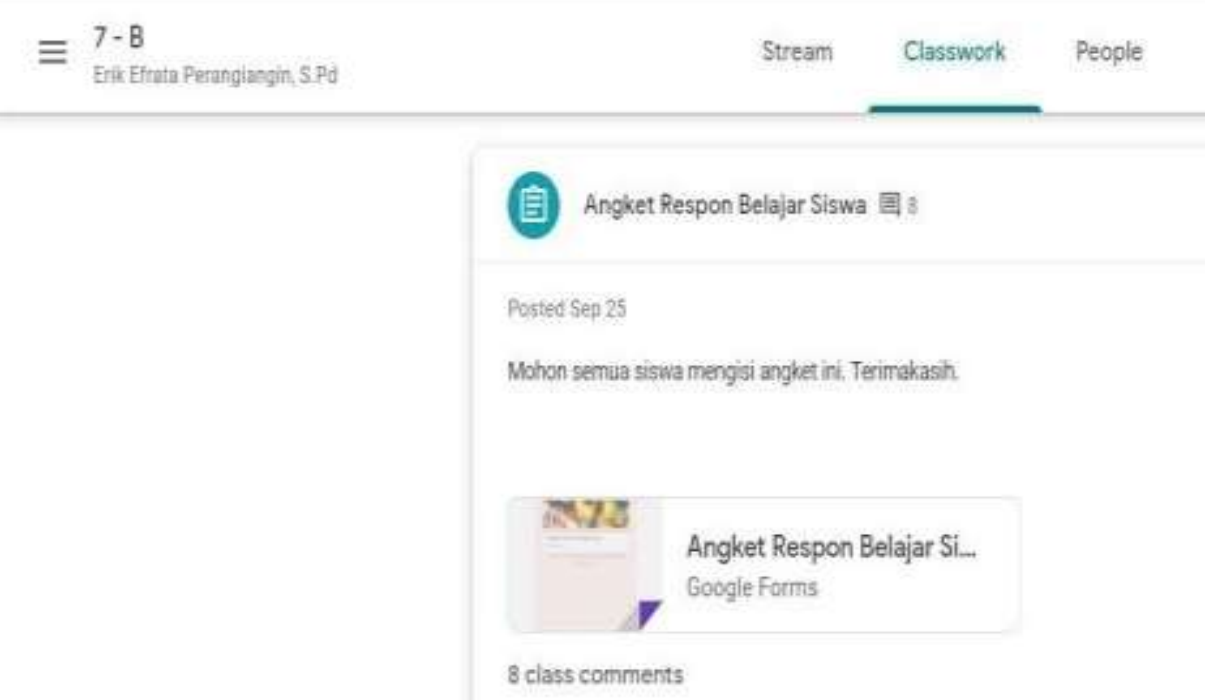

Figure 3. Google Form of Student Response Questionnaire 
follows:

The student response questionnaire is designed based on the grid, which is as

Table 1. Student Response Questionnaire Grid

\begin{tabular}{|c|c|c|c|c|}
\hline \multirow[b]{2}{*}{ Number } & \multirow[b]{2}{*}{ Indicator } & \multicolumn{2}{|c|}{ Questionnaire Item Number } & \multirow[b]{2}{*}{ Total } \\
\hline & & $\begin{array}{c}\text { Positive } \\
\text { Statement }\end{array}$ & $\begin{array}{l}\text { Negative } \\
\text { Statement }\end{array}$ & \\
\hline 1. & $\begin{array}{l}\text { Student interest in } \\
\text { learning methods }\end{array}$ & 1,4 & 13 & 3 \\
\hline 2. & $\begin{array}{l}\text { The benefits that } \\
\text { students get by using } \\
\text { learning methods }\end{array}$ & $\begin{array}{c}3,5,6,7,8 \\
9,14\end{array}$ & 10 & 8 \\
\hline 3. & $\begin{array}{l}\text { Contraints experienced } \\
\text { by students during the } \\
\text { learning process with } \\
\text { the learning method }\end{array}$ & - & 11,15 & 2 \\
\hline 4. & $\begin{array}{l}\text { Students' expectations } \\
\text { and suggestions for } \\
\text { learning methods }\end{array}$ & 12 & 2 & 2 \\
\hline & Total & 10 & 5 & 15 \\
\hline
\end{tabular}

As for interpretation of the questionnaire results percentage scale can be seen in the following table 2:

\begin{tabular}{cc}
\hline Score $(\%)$ & Criteria \\
\hline $0-20$ & very weak \\
$21-40$ & weak \\
$41-60$ & enough \\
$61-80$ & strong \\
$81-100$ & very strong \\
\hline
\end{tabular}

\section{Discussion}

Based on the research results obtained data on the percentage of student responses for each indicator. The data on the percentage of student responses to the indilator students' interest in learning with realistic mathematics creative module comics can be seen in the following table:

Table 3. Percentage of Each Item Response on Indicator 1

\begin{tabular}{ccccccccccccc}
\hline \multicolumn{2}{c}{ Item Number } & \multicolumn{2}{c}{ Strongly Agree } & \multicolumn{2}{c}{ Agree } & & Disagree Less & Disagree & \multicolumn{2}{c}{$\begin{array}{c}\text { Strongly } \\
\text { Disagree }\end{array}$} \\
\hline $\begin{array}{c}\text { Positive } \\
(+)\end{array}$ & $\begin{array}{c}\text { Negative } \\
(-)\end{array}$ & Frequency & $\%$ & Frequency & $\%$ & Frequency & $\%$ & Frequency & $\%$ & Frequency & $\%$ \\
\hline 1 & & 4 & 12,9 & 21 & 67,7 & 5 & 16,1 & 1 & 3,2 & 0 & 0 \\
\hline
\end{tabular}




\begin{tabular}{ccccccccccc}
\hline 4 & 2 & 6,5 & 22 & 71 & 4 & 12,9 & 3 & 9,7 & 0 & 0 \\
\hline & 13 & 3,2 & 6 & 19,4 & 12 & 38,7 & 8 & 25,8 & 4 & 12,9 \\
\hline Total & 7 & 22,6 & 49 & 158 & 21 & 67,7 & 12 & 38,7 & 4 & 12,9 \\
\hline Average & & 7,5 & & 52,7 & & 22,6 & & 12,9 & & 4,3 \\
\hline
\end{tabular}

Based on the table above, it states that the students' responses to comic-based learning in creative mathematics modules are realistic integer operation material on the indicators of student interest in learning methods and approaches, namely $7.5 \%$ stated that the average strongly agrees, $52.7 \%$ states the average agrees. $22.6 \%$ disagree on average, $12.9 \%$ disagree on average, and $4.3 \%$ on average strongly disagree. Based on the average percentage of student responses, it can be concluded that most students are interested in comicbased learning in creative mathematics realistic modules on integer operations material.

The percentage of student responses to comic-based learning in creative mathematics realistic modules on indicators of student interest in the method and approach as a whole is the data presented in the following table:

Table 4. The Cumulative Percentage of Student Responses to Indicator 1

\begin{tabular}{ccccc}
\hline $\begin{array}{c}\text { Item } \\
\text { Number }\end{array}$ & Score & Frequency & $\begin{array}{c}\text { Total } \\
\text { Score }\end{array}$ & $\%$ \\
\hline 5 & 10 & 50 & 14,84 \\
\hline $1,4,13$ & 3 & 51 & 204 & 60,53 \\
\hline 2 & 20 & 60 & 17,80 \\
\hline Total & 11 & 22 & 6,53 \\
\hline Highest Score & 1 & 1 & 0,30 \\
\hline Number of Statements & 93 & 337 & 100 \\
\hline Number of Respondents & & 5 & \\
\hline Maximum Score & 31 & \\
\hline Percent Average & & 465 & \\
\hline
\end{tabular}

Based on the table above, it is stated that for indicators of student interest in learning methods and approaches an average of $72.47 \%$ was obtained with the number of respondents 31 and the overall maximum score of 465 . The percentage acquisition was classified as strong.

Table 5. Percentage of Each Item Response in Indicator 2

\begin{tabular}{cccccccccccc}
\hline \multicolumn{1}{l}{ Item Number } & \multicolumn{2}{c}{$\begin{array}{c}\text { Strongly } \\
\text { Agree }\end{array}$} & Agree & & Disagree Less & Disagree & \multicolumn{2}{c}{$\begin{array}{c}\text { Stringly } \\
\text { Disagree }\end{array}$} \\
\hline $\begin{array}{c}\text { Posit } \\
\text { ive } \\
(+)\end{array}$ & $\begin{array}{c}\text { Negat } \\
\text { ive (-) }\end{array}$ & $\begin{array}{c}\text { Freque } \\
\text { ncly }\end{array}$ & $\%$ & $\begin{array}{c}\text { Frekque } \\
\text { ncly }\end{array}$ & $\%$ & $\begin{array}{c}\text { Freque } \\
\text { ncly }\end{array}$ & $\%$ & $\begin{array}{c}\text { Freque } \\
\text { ncly }\end{array}$ & $\%$ & $\begin{array}{c}\text { Freque } \\
\text { ncly }\end{array}$ & $\%$ \\
\hline
\end{tabular}




\begin{tabular}{|c|c|c|c|c|c|c|c|c|c|c|}
\hline 3 & 5 & $\begin{array}{c}16 \\
1\end{array}$ & 22 & 71 & 4 & $\begin{array}{c}12 \\
9\end{array}$ & 0 & 0 & 0 & 0 \\
\hline 5 & 7 & $\begin{array}{c}22, \\
6\end{array}$ & 19 & $\begin{array}{c}61, \\
3\end{array}$ & 4 & $\begin{array}{c}12 \\
9\end{array}$ & 1 & $\begin{array}{l}3, \\
2\end{array}$ & 0 & 0 \\
\hline 6 & 4 & $\begin{array}{c}12, \\
9\end{array}$ & 22 & 71 & 5 & $\begin{array}{c}16, \\
1\end{array}$ & 0 & 0 & 0 & 0 \\
\hline 7 & 8 & $\begin{array}{c}25 \\
8\end{array}$ & 21 & $\begin{array}{c}67 \\
7\end{array}$ & 2 & 6,5 & 0 & 0 & 0 & 0 \\
\hline 8 & 8 & $\begin{array}{c}25 \\
8\end{array}$ & 19 & $\begin{array}{c}61, \\
3\end{array}$ & 4 & $\begin{array}{c}12 \\
9\end{array}$ & 0 & 0 & 0 & 0 \\
\hline 9 & 5 & $\begin{array}{c}16, \\
1\end{array}$ & 24 & $\begin{array}{c}77 \\
4\end{array}$ & 2 & 6,5 & 0 & 0 & 0 & 0 \\
\hline \multirow[t]{2}{*}{14} & 4 & $\begin{array}{c}12 \\
9\end{array}$ & 26 & $\begin{array}{c}83 \\
9\end{array}$ & 1 & 3,2 & 0 & 0 & 0 & 0 \\
\hline & 3 & 9,7 & 4 & $\begin{array}{c}12 \\
9\end{array}$ & 11 & $\begin{array}{c}35 \\
5\end{array}$ & 9 & 29 & 4 & $\begin{array}{l}12 \\
, 9\end{array}$ \\
\hline Total & 44 & $\begin{array}{c}141 \\
, 9\end{array}$ & 157 & $\begin{array}{c}506 \\
, 5\end{array}$ & 33 & $\begin{array}{c}106 \\
, 5\end{array}$ & 10 & $\begin{array}{c}32 \\
, 2\end{array}$ & 4 & $\begin{array}{l}12 \\
, 9\end{array}$ \\
\hline Average & & $\begin{array}{l}17 \\
74\end{array}$ & & $\begin{array}{l}63, \\
31\end{array}$ & & $\begin{array}{l}13, \\
31\end{array}$ & & $\begin{array}{l}4, \\
03\end{array}$ & & $\begin{array}{l}1, \\
61\end{array}$ \\
\hline
\end{tabular}

Based on the table above, it states that students' responses to comic-based learning in creative mathematics modules are realistic integer operation material on the indicators of benefits that students get by using these learning methods and approaches, namely $17.74 \%$, which states that the average strongly agrees, $63.31 \%$ stated On average, $13.31 \%$ agreed, on average they disagree, $4.03 \%$ on average disagree, and $1.61 \%$ on average disagree. Based on the average percentage of student responses, it can be concluded that most of the students benefited from the application of the comic-based learning method and approach to the creative mathematics module realistic integer operation material.

The percentage of student responses to comic-based learning in creative mathematics realistic modules on the indicators of the benefits that students get by using these learning methods and approaches as a whole is the data presented in the following table:

Table 6. Percentage of Cumulative Student Responses on Indicator 2

\begin{tabular}{ccccc}
\hline \multirow{2}{*}{$\begin{array}{c}\text { Item } \\
\text { Number }\end{array}$} & Score & Frequencly & $\begin{array}{c}\text { Total } \\
\text { Score }\end{array}$ & $\%$ \\
\hline & 5 & 46 & 230 & 23,40 \\
\cline { 2 - 5 } $3,5,6,7$, & 4 & 160 & 640 & 65,11 \\
$8,9,10$, & 3 & 32 & 96 & 9,77 \\
14 & 2 & 7 & 14 & 1,42 \\
\cline { 2 - 5 } & 1 & 3 & 3 & 0,30 \\
\hline
\end{tabular}




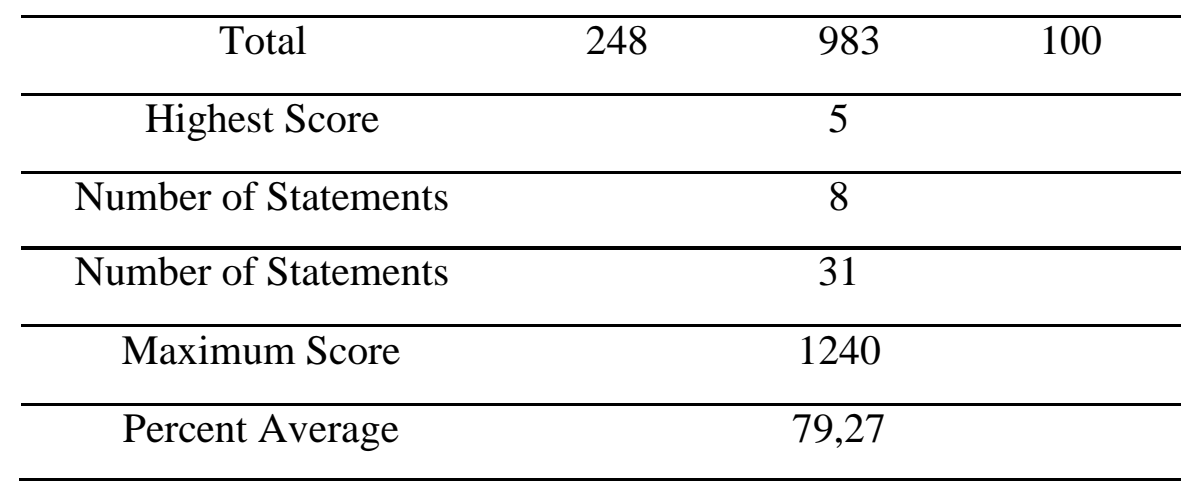

Based on the table above, it is stated that for the indicators of benefits obtained by students by using the learning method and approach, an average of $79.27 \%$ was obtained with the number of respondents 31 and the overall maximum score of 1240. The percentage acquisition was classified in the strong category.

Table 7. Percentage of Each Item Response on Indicator 3

\begin{tabular}{|c|c|c|c|c|c|c|c|c|c|c|c|}
\hline \multicolumn{2}{|c|}{$\begin{array}{l}\text { Number } \\
\text { Item }\end{array}$} & \multicolumn{2}{|c|}{$\begin{array}{c}\text { Strongly } \\
\text { Agree }\end{array}$} & \multicolumn{2}{|c|}{ Agree } & \multicolumn{2}{|c|}{$\begin{array}{c}\text { Disagree } \\
\text { Less }\end{array}$} & \multicolumn{2}{|c|}{ Disagree } & \multicolumn{2}{|c|}{$\begin{array}{l}\text { Strongly } \\
\text { Disagree }\end{array}$} \\
\hline $\begin{array}{c}\text { Posit } \\
\text { tive } \\
(+) \\
\end{array}$ & $\begin{array}{c}\text { Nega } \\
\text { tive } \\
(-) \\
\end{array}$ & $\begin{array}{l}\text { Frequ } \\
\text { ency }\end{array}$ & $\%$ & $\begin{array}{l}\text { Frequ } \\
\text { ency }\end{array}$ & $\%$ & $\begin{array}{l}\text { Frequ } \\
\text { ency }\end{array}$ & $\%$ & $\begin{array}{l}\text { Frequ } \\
\text { ency }\end{array}$ & $\%$ & $\begin{array}{l}\text { Frequ } \\
\text { ency }\end{array}$ & $\%$ \\
\hline & 11 & 2 & $\begin{array}{l}6 \\
4\end{array}$ & 15 & $\begin{array}{c}48 \\
4\end{array}$ & 8 & $\begin{array}{r}25 \\
, 8\end{array}$ & 6 & $\begin{array}{r}19 \\
4\end{array}$ & 0 & 0 \\
\hline & 15 & 1 & $\begin{array}{l}3, \\
2\end{array}$ & 20 & $\begin{array}{c}64 \\
5\end{array}$ & 7 & $\begin{array}{l}22 \\
, 6\end{array}$ & 1 & $\begin{array}{l}3, \\
2\end{array}$ & 2 & $\begin{array}{l}6, \\
5\end{array}$ \\
\hline \multicolumn{2}{|c|}{ Total } & 3 & $\begin{array}{l}9 \\
6 \\
\end{array}$ & 35 & $\begin{array}{l}11 \\
2,9 \\
\end{array}$ & 15 & $\begin{array}{r}48 \\
, 4 \\
\end{array}$ & 7 & $\begin{array}{r}22 \\
, 6 \\
\end{array}$ & 2 & $\begin{array}{l}6, \\
5\end{array}$ \\
\hline \multicolumn{2}{|c|}{ Average } & & $\begin{array}{l}4, \\
8\end{array}$ & & $\begin{array}{l}56, \\
45\end{array}$ & & $\begin{array}{l}24 \\
, 2\end{array}$ & & $\begin{array}{l}11 \\
, 3\end{array}$ & & $\begin{array}{l}3, \\
25\end{array}$ \\
\hline
\end{tabular}

Based on the table above, it states that the students' responses to comic-based learning in creative mathematics modules are realistic integer operation material on the indicators of constraints experienced by students during the learning process using these learning methods and approaches, namely $4.80 \%$, which means that the average strongly agrees, $5645 \%$ stated that on average agree, $24.20 \%$ stated that on average they disagree, $11.30 \%$ on average disagree, and $3.25 \%$ on average strongly disagree. Based on the average percentage of student responses, it can be concluded that a small proportion of students experienced problems during the learning process by applying learning methods and approaches based on comics based on realistic mathematics creative modules on integer operations material.

The percentage of student responses to comic-based learning based on creative mathematics realistic modules on the indicators of constraints experienced by students using these learning methods and approaches as a whole is the data presented in the following table: 
Table 8. The Cumulative Percentage of Student Responses to Indicator 3

\begin{tabular}{ccccc}
\hline $\begin{array}{c}\text { Item } \\
\text { Number }\end{array}$ & Score & Frequency & $\begin{array}{c}\text { Total } \\
\text { Score }\end{array}$ & $\%$ \\
\hline 5 & 2 & 10 & 6,41 \\
\hline 11,15 & 3 & 7 & 28 & 17,95 \\
\hline 2 & 35 & 70 & 44,87 \\
\hline Total & 3 & 3 & 1,92 \\
\hline Highest Score & 62 & 156 & 100 \\
\hline Number of Statement & & 5 & \\
\hline Number of Respondent & & 2 & \\
\hline Maximum Score & 31 & \\
\hline Percent Average & 310 & \\
\hline
\end{tabular}

Based on the table above, it states that for the indicators of obstacles experienced by students during the learning process with the learning method and approach, an average of $50.32 \%$ was obtained with the number of respondents 31 and an overall maximum score of 310. The percentage acquisition was classified in the sufficient category.

Table 9. Percentage of Each Item Response on Indicator 4

\begin{tabular}{|c|c|c|c|c|c|c|c|c|c|c|c|}
\hline \multicolumn{2}{|c|}{$\begin{array}{c}\text { Item } \\
\text { Number }\end{array}$} & \multicolumn{2}{|c|}{$\begin{array}{c}\text { Strongly } \\
\text { Agree }\end{array}$} & \multicolumn{2}{|c|}{ Agree } & \multicolumn{2}{|c|}{$\begin{array}{c}\text { Disagree } \\
\text { Less } \\
\end{array}$} & \multicolumn{2}{|c|}{ Disagree } & \multicolumn{2}{|c|}{$\begin{array}{l}\text { Strongly } \\
\text { Disagree } \\
\end{array}$} \\
\hline $\begin{array}{c}\text { Posit } \\
\text { ive } \\
(+)\end{array}$ & $\begin{array}{l}\text { Negat } \\
\text { ive (-) }\end{array}$ & $\begin{array}{c}\text { Freque } \\
\text { ncy }\end{array}$ & $\%$ & $\begin{array}{c}\text { Freque } \\
\text { ncy }\end{array}$ & $\%$ & $\begin{array}{c}\text { Freque } \\
\text { ncy }\end{array}$ & $\%$ & $\begin{array}{c}\text { Freque } \\
\text { ncy }\end{array}$ & $\%$ & $\begin{array}{c}\text { Freque } \\
\text { ncy }\end{array}$ & $\%$ \\
\hline \multirow[t]{2}{*}{12} & & 9 & 29 & 22 & 71 & 0 & 0 & 0 & 0 & 0 & 0 \\
\hline & 2 & 3 & 9,7 & 20 & $\begin{array}{c}64, \\
5\end{array}$ & 6 & $\begin{array}{l}19 \\
4\end{array}$ & 1 & $\begin{array}{l}3, \\
2\end{array}$ & 1 & $\begin{array}{l}3, \\
2\end{array}$ \\
\hline \multicolumn{2}{|c|}{ Total } & 12 & $\begin{array}{c}38, \\
7\end{array}$ & 42 & $\begin{array}{c}135 \\
, 5\end{array}$ & 6 & $\begin{array}{l}19 \\
4\end{array}$ & 1 & $\begin{array}{l}3, \\
2\end{array}$ & 1 & $\begin{array}{l}3, \\
2,\end{array}$ \\
\hline \multicolumn{2}{|c|}{ Average } & & $\begin{array}{l}19, \\
35\end{array}$ & & $\begin{array}{l}67, \\
75\end{array}$ & & $\begin{array}{l}9 \\
7\end{array}$ & & $\begin{array}{l}1, \\
6\end{array}$ & & $\begin{array}{l}1, \\
6\end{array}$ \\
\hline
\end{tabular}

Based on the table above, it states that students 'responses to comic-based learning in creative mathematics modules are realistic integer operation material on the indicators of students' expectations and suggestions for this learning method. Strongly agree, $67.75 \%$ stated on average agree, $9.70 \%$ stated on average disagree, $1.60 \%$ on average disagree, and $1.60 \%$ on average strongly disagree. Based on the average percentage of student responses, it can be concluded that most of the students hoped and suggested that comic-based 
learning methods and approaches be applied in creative mathematics realistic modules on integer operations material.

As for the percentage of student responses to comic-based learning based on realistic mathematics creative modules on the indicators of student expectations and suggestions for learning methods and approaches as a whole, the data are presented in the following table:

Table 10. The Cumulative Percentage of Student Responses to Indicator 4

\begin{tabular}{ccccc}
\hline \multirow{2}{*}{$\begin{array}{c}\text { Item } \\
\text { Number }\end{array}$} & Score & Frequency & $\begin{array}{c}\text { Total } \\
\text { Score }\end{array}$ & $\%$ \\
\hline \multirow{2}{*}{2,12} & 5 & 11 & 55 & 26,57 \\
\cline { 2 - 5 } & 4 & 23 & 92 & 44,44 \\
\cline { 2 - 5 } & 2 & 6 & 18 & 8,70 \\
\cline { 2 - 5 } & 1 & 20 & 40 & 19,32 \\
\hline Total & 62 & 207 & 0,97 \\
\hline Highest Score & & 5 & 100 \\
\hline Number of Statement & & 2 & \\
\hline Number of Respondent & & 31 & \\
\hline Maximum Score & 310 & \\
\hline Percent Average & 66,77 \\
\hline
\end{tabular}

Based on the table above, it states that for the indicators of student expectations and suggestions for the learning method and approach, an average of $66,77 \%$ was obtainded with the number of respondents 31 and the overall maximum score of 310 . The percentage acquisition was classified in the strong category. The recapitulation of the percentage of student responses to comic-based learning in realistice mathematics creative modules is as follows:

Table 11. Recapitulation of Percentage of Student Response Questionnaires in Learning Comic-Based Realistic Creative Mathematics Module

\begin{tabular}{lllllll}
\hline & \multicolumn{7}{c}{ Statements (\%) } & & & \\
\cline { 2 - 6 } Indicator & $\begin{array}{l}\text { Strongl } \\
\text { y Agree }\end{array}$ & Agree & $\begin{array}{l}\text { Disagr } \\
\text { ee } \\
\text { Less }\end{array}$ & $\begin{array}{l}\text { Disagr } \\
\text { ee }\end{array}$ & $\begin{array}{l}\text { Disagr } \\
\text { ee Less }\end{array}$ & Total \\
\hline $\begin{array}{l}\text { Student interest in } \\
\text { learning methods }\end{array}$ & 7,50 & 52,7 & 22,60 & 12,90 & 4,30 & 100 \\
\hline $\begin{array}{l}\text { The benefits that } \\
\text { students get by using } \\
\text { learning methods }\end{array}$ & 17,74 & 63,31 & 13,31 & 4,03 & 1,61 & 100 \\
\hline
\end{tabular}




\begin{tabular}{l}
$\begin{array}{l}\text { Constraints experienced } \\
\text { by students during the } \\
\text { learning process with } \\
\text { the learning method }\end{array}$ \\
$\begin{array}{l}\text { Students' expectations } \\
\text { and suggestions for } 19,35\end{array}$ \\
$\begin{array}{l}\text { learning methods } \\
\text { Average }\end{array}$ \\
\hline
\end{tabular}

In the table above it is known that students' responses to learning using realistic mathematics comics on integer operation material obtained an average of $12.35 \%$ dat that strongly agree, $60.05 \%$ agree, $17.45 \%$ disagree, $7.46 \%$ disagree, and $2.69 \%$ strongly disagree. The results of comparison recapitulation on each student response indicator can be seen in the table below:

Table 12. Recapitulation of Comparison of Percentage of Student Response for Each Indicator

\begin{tabular}{lcc}
\hline \multicolumn{1}{c}{ Indicator } & Percentage & Interpretation \\
\hline $\begin{array}{l}\text { Student interest in } \\
\text { learning methods }\end{array}$ & 72,47 & Strong \\
\hline $\begin{array}{l}\text { The benefits that } \\
\text { students get by using } \\
\text { learning methods }\end{array}$ & 79,27 & Strong \\
\hline $\begin{array}{l}\text { Constraints experienced } \\
\text { by student during the } \\
\text { learning process with } \\
\text { the learning method }\end{array}$ & 50,32 & Enough \\
\hline $\begin{array}{l}\text { Students' expectations } \\
\text { and suggestions for } \\
\text { learning methods }\end{array}$ & 66,77 & Strong \\
\hline
\end{tabular}

Based on the data above, it is stated that the student's response is positive to learning using the realistic mathematics creative module comic. It can be seen from the large percentage of student interest and the benefits students get through the implementation of learning.

In learning mathematics, of course, student responses vary. The response is observed when the learning activity is carried out. Teachers have an important role in creating porsitive student responses. Through this research, an analysis of student responses was generated. Based on the available data, it is known that the students; response is positive to learning using the creative mathematics module comic realistic integer operation material. This learning is online learning that is applied through the google classroom application. Based on student responses indicators which include student interest and benefits obtained by students, it its known that the average percentage is in the strong (high) category. However, in the implementation of learning there are students who experience obstacles but thes obstacles can be overcome. In addition, students also put hopes and suggestions on learning methods and approaches to be implemented as well as possible and minimize obstacles in its implementation. 


\section{Conclusion}

Based on the results and discussion above, it can be concluded that the student's response is positive to learning using the realistic mathematics creative module comic. This concludes based on the percentage of interest and benefits obtained by students is greater than the obstacles experienced by students when learning by using realistic mathematics creative module comics. Through the analysis that has been carried out, it is hoped that it can become input and ideas for teachers, prospective teachers, or educators that learning using comics gives students a positive response to mathematics learning.

\section{Recommendations}

This research is an interesting one to know because learning using comics creates a positive response among students. The comic which is designed is a comic for realistic mathematics learning module specifically for integer operations. In the implementation of online learning, the comics are presented in the form of learning videos that are distributed to students. Therefor it is recommended for teachers, prospective teachers, or educators to implement learning using these media because after being analyzed it is known that student responses are positive to learning methods and approaches using these media.

\section{Acknowledgements}

In this section, the authors would like to thank the Ministry of Research and Technology/ National Research and Innovation Agency based on Decree Number: 8/E1/KPT/2020 and the Chairperson of the Region I Higher Education Service Institute and the Institute for Research and Community Service of the Catholic University of Saint Thomas according to with research contract number 196/LL1/PG/2020 which has provided support and assistance for research results can be published. The authors hopes that this article can be useful as input for ideas for teachers and prospective teachers and other researchers in creating quality learning in schools, especially in mathematics.

\section{References}

A. Mamolo, L. (2019). Development of digital interactive math comics (DIMaC) for senior high school students in general mathematics. Cogent Education. 1-13.

Celsie Puji Lestari, A., dan Rooselyna Ekawat. (2019). Development Of Education Comics Based Realistic Mathematics Education On Fraction Material. Jurnal Riset Pendidikan dan Inovasi Pembelajaran Matematika (JRPIPM). 3(1). 15-23.

Dalvi, T., and Anna Hofmann. Towards Answering, What Do We Know about Elementary Pre-Service Teachers' Noticing Skills in Science? A Pre-Requisite to Prepare Them to Teach Responsively in Science Classrooms. Creative Education. 10. 332-352.

Deligianni-Georgaka, A. and Qurania Pouroutidi. (2016). Creating digital comics to motivate young learners to write: a case study. Research Papers in Language Teaching and Learning. 7(1). 233-263.

Dwi Arinii, F., Abdul Salim Choiri, Sunardi. (2017). The Use of Comic as A Learning Aid to Improve Learning Interest of Slow Learner Student. European Journal of Special Education Research. 2(1). 71-78. 
Harahap, E., et al. (2020). Determinant Analysis of Education Inequalities in Indonesia. Budapest International Research and Critics Institute-Journal (BIRCI-Journal). P. 10671082.

Husna, Dwi Wahyuni, Suratno, I Ketut Mahardika, and lis Nur Asyiah. (2019). Analysis of Students' Response to The Model of Problems Based Contextual Learning on Science Learning. International Journal of Advanced Research (IJAIR). 7(1). 408411.

Kamil, A., Endang Komariah, and Yuliana. (2017). The Use of Comic to Improve Students' Reading Comprehension Skill at Junior High School. Research in English and Education (READ). 2 (3). 1-7.

Meilantifa, et. al. (2019). Mathematical Comics on Class X Trigonometry Learning. 1st International Conference on Advance and Scientific Innovation (ICASI). IOP Conf. Series: Journal of Physics: Conf. Series 1175.1-5.

Musdiani, et al. (2019). Analysis the Role of Headmaster in Applying Quality of Education in Primary School Districts, Aceh Barat. Budapest International Research and Critics in Linguistics and Education (BirLE) Journal. P. 27-35.

M. Wright, C. (2018). Revising the Definition of Formative Assessment. Council of Chief State School Officers: Washington, DC.

Saputra, A. (2018). Allocation of Education Budget in Indonesia. Budapest International Research and Critics Institute-Journal (BIRCI-Journal).P. 142-148

Sipayung, T. N., Sinta Dameria Simanjuntak, Ariyadi Wijaya, Sugiman. (2019). Multicultural Education. 5(1). 117-126.

Versac, R. (2001). How Comic Books Can Change the Way Our Students See Literature: One Teacher's Perspec. English journal. 61-67.

Wong. A. (2016). Student perception on a student response system formed by combining mobile phone and a polling website. 12(1). 144-153. 